\title{
The liquid biopsy in lung cancer
}

\author{
Junaid Ansari ${ }^{1,2}$, Jungmi W. Yun ${ }^{2}$, Anvesh R. Kompelliं ${ }^{3}$, Youmna E. Moufarrej ${ }^{3}$, \\ Jonathan S. Alexander ${ }^{2}$, Guillermo A. Herrera ${ }^{4}$, and Rodney E. Shackelford ${ }^{4}$ \\ ${ }^{1}$ Feist Weiller Cancer Center, LSU Health Shreveport, LA, USA \\ 2 Department of Molecular and Cellular Physiology, LSU Health Sciences Center, Shreveport, LA, USA \\ ${ }^{3}$ School of Medicine, LSU Health Shreveport, Shreveport, LA, USA \\ ${ }^{4}$ Department of Pathology, LSU Health Shreveport, Shreveport, LA, USA \\ Correspondence to: Rodney Shackelford, email: rshack@lsuhsc.edu \\ Keywords: circulating tumor cells, circulating cell-free tumor DNA, liquid biopsy, tumor educated platelets, epidermal growth fac- \\ tor receptor \\ Received: December 16, $2016 \quad$ Accepted: January 13,2017 Published: January 18, 2017
}

\section{ABSTRACT}

The incidence of lung cancer has significantly increased over the last century, largely due to smoking, and remains the most common cause of cancer deaths worldwide. This is often due to lung cancer first presenting at late stages and a lack of curative therapeutic options at these later stages. Delayed diagnoses, inadequate tumor sampling, and lung cancer misdiagnoses are also not uncommon due to the limitations of the tissue biopsy. Our better understanding of the tumor microenvironment and the systemic actions of tumors, combined with the recent advent of the liquid biopsy, may allow molecular diagnostics to be done on circulating tumor markers, particularly circulating tumor DNA. Multiple liquid biopsy molecular methods are presently being examined to determine their efficacy as surrogates to the tumor tissue biopsy. This review will focus on new liquid biopsy technologies and how they may assist in lung cancer detection, diagnosis, and treatment.

\section{INTRODUCTION}

Lung cancer (LC) is the second most commonly diagnosed cancer and remains the leading cause of cancer deaths worldwide, with an estimated 1.8 million new cases in 2012 [1]. Smoking is the main risk factor, with other risk factors being genetic predisposition, and environmental exposures such as radon, arsenic, polycyclic aromatic hydrocarbons, and asbestos $[1,2]$. Currently the 5 -year overall survival rate for lung cancer is $17-22 \%$, although survival differs with different stages at initial diagnosis. The low survival rate in LC is partially due to only $20 \%$ of LCs diagnosed at early stages, with the remaining diagnosed at later stages, often precluding curative treatment [1-3]. When detection methods are used that allow earlier diagnoses, LC survival increases. For example, compared to the standard chest X-ray, spiral computed tomography (CT) reduces LC mortality by $20 \%$ due to earlier detection [4]. The high morbidity and mortality associated with LC and the improved survival with earlier detection methods highlights the need for better early detection methods, especially as many patients who achieve an initial remission have recurrences [1-4].
LC is subdivided into small cell LC (SCLC) and non-small cell LC (NSCLC), constituting approximately $15 \%$ and $85 \%$ of LCs, respectively [5]. NSCLC is further subdivided into adenocarcinoma (AdenoCA), squamous cell carcinoma (SCC), and several less common subtypes [5]. Presently pulmonary AdenoCAs are usually analyzed for epidermal growth factor receptor (EGFR) activating mutations, and ROS1 and anaplastic lymphoma tyrosine kinase (ALK) gene rearrangements, as these molecular changes have targeted therapies that improve treatment outcomes [5-8]. The most common different LC subtypes, their prognoses, and immunohistochemical and molecular markers are summarized in Table 1.

Such markers often guide patient treatment options and confer valuable prognostic information. For example, late-stage AdenoCAs with activating EGFR mutations can be treated with the first or second-line anti-EGFR tyrosine kinase inhibitor (TKI) drugs erlotinib, gefitinib, or afatinib. All which show superior response rates and outcomes compared to standard chemotherapy $[5,6]$. Similarly, specific chemotherapeutic drugs block the activities of mutated EML-ALK, BRAF, and ROS1 kinases in AdenoCAs, improving clinical outcomes [9- 
Table1: A summary of the features of the most common lung cancer subtypes, including the prognosis by 5-year survival at different stages, the LC type immunohistochemistries commonly used in diagnosis, common histologic features, and common molecular alterations.

\begin{tabular}{|c|c|c|c|c|c|}
\hline NSCLC & $\begin{array}{l}\text { Prognosis } \\
\text { 5-yr } \\
\text { Survival } \\
\text { by Stage }\end{array}$ & Histology & IHC & Genes Mutated & References \\
\hline $\begin{array}{l}\text { Adenocarcinoma } \\
\sim 60 \% \text { of NSCLC }\end{array}$ & \multirow{2}{*}{$\begin{array}{l}\text { IA }-49 \% \\
\text { IB }-45 \% \\
\text { IIA }-30 \% \\
\text { IIA }-30 \% \\
\text { IIB }-31 \% \\
\text { IIIA - } 14 \% \\
\text { IIIB - 5\% } \\
\text { IV }-1 \%\end{array}$} & $\begin{array}{l}\text { Glandular differentiation with } \\
\text { prominent nucleoli in lepidic, } \\
\text { papillary, solid, and/or acinar } \\
\text { growth patterns. }\end{array}$ & $\begin{array}{l}\text { CK7+ } \\
\text { TTF-1+ } \\
\text { Napsin A+ } \\
\text { CK20- }\end{array}$ & $\begin{array}{l}\text { p53 Mt } 90 \% \\
\text { KRAS Mt } 32.2 \% \\
\text { EGFR Mt } 15 \% \\
\text { FGFR4 Mt } 7 \% \\
\text { ALK Fus } 3.9 \% \\
\text { BRAF Mt } 7 \% \\
\text { ROS1 Fus } 2 \% \\
\text { c-MET Amp } 4 \% \\
\text { RET Fus } 1 \% \\
\text { HER2 Mt } 0.9 \%\end{array}$ & $\begin{array}{l}{[5],[7-13],} \\
{[15],[16]}\end{array}$ \\
\hline $\begin{array}{l}\text { Squamous } \\
\text { Carcinoma } \\
20-30 \% \text { of } \\
\text { NSCLC }\end{array}$ & & $\begin{array}{l}\text { Polygonal cells in island } \\
\text { or sheets with intercellular } \\
\text { bridges, eosinophilic cytoplasm, } \\
\text { prominent nucleoli, and may } \\
\text { have keratin pearl formation. }\end{array}$ & $\begin{array}{l}\text { p63+, CK5/6+, } \\
\text { p40+, CEA+, } \\
\text { EMA+ } \\
\text { CK7-, TTF-1- }\end{array}$ & $\begin{array}{l}\text { p53 Mt 90\% } \\
\text { FGFR1 Amp 20\% } \\
\text { PIK3CA Mt } 12 \% \\
\text { PTEN Mt } 10 \% \\
\text { KRAS Mt } 6 \% \\
\text { EGFR Mt } 5 \% \\
\text { DDR2 Mt } 4 \% \\
\text { BRAF Mt } 2 \%\end{array}$ & $\begin{array}{l}{[5], \quad[9],} \\
{[17-26]}\end{array}$ \\
\hline $\begin{array}{l}\text { Small Cell Lung } \\
\text { Cancer } \\
15-20 \% \text { of lung } \\
\text { cancers } \\
99 \% \text { occur in } \\
\text { smokers }\end{array}$ & $\begin{array}{l}\text { I }-31 \% \\
\text { II }-19 \% \\
\text { III }-8 \% \\
\text { IV }-2 \%\end{array}$ & $\begin{array}{l}\text { Round-oval cells with nuclear } \\
\text { molding, crush artifact, "salt } \\
\text { and pepper" chromatin, absent } \\
\text { nucleoli, and a brisk mitotic rate. }\end{array}$ & $\begin{array}{l}\text { pan-keratin+, } \\
\text { TTF-1+, NSE+, } \\
\text { CD117+, } \\
\text { CD57+ } \\
\text { chromogranin }+ \text {, } \\
\text { synaptophysin+ }\end{array}$ & $\begin{array}{l}\text { p53 Mt 90\% } \\
\text { RB1 Mt } 60 \% \\
\text { KRAS Mt } 25 \% \\
\text { RET Fus } 5 \% \\
\text { EGFR Mt } 4 \% \\
\text { PIK3CA Mt 3\% } \\
\text { ROS1 Fus } 1 \%\end{array}$ & {$[27-34]$} \\
\hline
\end{tabular}

11]. For EML-ALK positive AdenoCAs treatment with the drug crizotinib significantly increases overall patient survival and progression free survival [8]. Additionally, LC often has epigenetic changes, such as increased p16, RASSF1, APC, and H-cadherin gene promotor methylations, which down-regulates tumor suppressor gene expression, promoting cancer progression [12]. Presently new therapies targeting LC epigenetic changes are being developed and some have already shown utility in LC treatment [13].

In LC diagnosis and staging, imaging and diagnostic biopsies play central roles. Currently, CT is often employed in LC diagnosis and staging, but many lung nodules are still found incidentally by chest X-ray [4]. Positron emission tomography (PET) may be a useful modality in the work up of a suspected LC and often allows the distinction of benign from malignant lesions. However, concerns over false positives due to inflammation or false negatives due to small and less metabolically active nodules, or nodules with a low number of tumors cells, are flaws with PET [14].

In order to create a molecular profile of a tumor, a biopsy or several biopsies may be required. Recurrent biopsies are invasive and may miss portions of the tumor that are developing treatment resistance or have acquired new driver mutations [15]. Additionally, in phase 3 IPASS and INTEREST studies, only $42 \%$ and $31 \%$ of LC patients had tissue available or obtainable, respectively, limiting needed molecular diagnostic studies [16-18]. Lastly, recent studies reveal that malignant tumors have significant molecular heterogeneity, with cells from one portion of a tumor having different mutations than other areas and sometimes sharing only one-third of the mutations throughout the tumor [19]. Therefore minimally invasive modalities that could guide early detection, follow patients regularly, allow early emerging treatment resistance assessment, and identify new driver mutations would be useful in optimizing LC care [20].

Recent work on blood-based biomarker analyses, including circulating cell-free tumor DNA (cfDNA), 
circulating tumor cells (CTCs), and tumor-educated platelets (TEPs), indicate that these biomarkers may allow earlier LC detection with more frequent monitoring. Additionally, these techniques are less invasive and may provide a more complete LC molecular characterization [20-22]. These markers may also allow earlier minimal residual disease monitoring, as tumor cfDNA can be detected at a $50^{6}$ tumor cell burden, while PET requires a $10^{9}$ tumor cell burden for detection [23].

\section{THE LIQUID BIOPSY AND TUMOR MICRO- AND SYSTEMIC ENVI- RONMENTS}

Stromal-tumor interactions, referred to as the tumor microenvironment, play an important role in regulating tumor progression and metastatic potential [21, 22]. These interactions include paracrine/juxtacrine signals, and cytokine, cfDNA, and CTC release. Stromal-tumor interactions additionally lead to abnormal tumor-altered cellular phenotypes consisting of TEPs, tumor-associated neutrophils (TANs), cancer-associated fibroblasts (CAFs), and tumor endothelial cells (TECs) [21-25]. Additionally tumors extrude microvesicles (ES) containing lipids, proteins, DNA, and microRNAs, which modulate tumor behavior and stromal-host responses [22]. Lastly, tumors also create a systemic environment where soluble circulating tumor-derived factors recruit cells from organs, such as the spleen and bone marrow, to the tumor site. These processes often enhance local tumor growth and increase tumor metastatic potential [24]. Several of these circulating tumor-derived substances are easily sampled by a blood draw and can be subjected to molecular analyses. These include cfDNA, CTCs, TEPs, and ES $[20,21,23-25]$.

\section{cfDNA}

Tumor cfDNA was discovered in 1948 and is a promising LC molecular diagnostic target [26, 27]. cfDNA is partially composed of DNA fragments roughly 150 to 1,000 base-pairs long which form a ladder-like electrophoretic pattern of roughly $180 \mathrm{bp}$ multimers, possibly indicating an apoptotic origin [27-29]. However, other studies have shown that a significant portion of tumor-derived cfDNA is smaller than $145 \mathrm{bp}$, arguing against an apoptotic origin [30, 31]. cfDNA from cancer patients also contains hTERT and hTr gene sequences, which are not found in apoptosis-derived DNA. Other larger cfDNA fragments may be derived from necrotic tumor tissue; however, cfDNA levels fall following radiation therapy, suggesting that tumor necrosis is not a major cfDNA source [32-36]. Interestingly, some studies indicate that cfDNA may be actively secreted and have signaling functions promoting metastases (termed "genometastasis") [37-39]. For example, Garcia-Olmo et al. [38] found that NIH-3T3 murine cells incubated in the cell-free plasma of individuals with KRAS mutation-positive colorectal carcinoma developed KRAS mutations. When these cells were injected into mice, the mice grew tumors with human KRAS mutations, and the same mutations were detected in the murine plasma. Similarly, Trejo-Becerril et al. [39] showed that NIH-3T3 cells incubated in cell-free KRAS mutationpositive human serum developed KRAS mutations. When these cells were injected into rats with the colon cancer-initiating carcinogen 1,2-dimethylhydrazine, the rats developed KRAS-positive tumors. Although still under intense investigation, it appears that tumor-derived cfDNA has multiple origins and can act as a signaling molecule [27-39]. These findings are interesting in light of the observation by Jiang et al. [40] who found that tumors preferentially release tumor DNA bearing tumorassociated mutations.

Tumor cfDNA is found in blood, lymph, milk, spinal fluid, urine, and saliva and can be nuclear and/or mitochondrial [41]. It is less stable than cfDNA derived from non-tumor cells and is rapidly degraded by plasma nucleases, conferring a short half-life [41-43]. In one study the half-life of colorectal adenocarcinoma cfDNA (following a colon cancer resection) was 114 minutes [43]. LC cfDNA is generally higher in SCLC than in NSCLC and its plasma concentration often increases at higher tumor stages [44-46]. Additionally, Szpechcinski et al. [47] used realtime PCR to quantify cfDNA in 40 healthy volunteers, 101 individuals with chronic respiratory inflammation, and 50 stage I-IIIA NSCLC patients. cfDNA was $2.27+/-1.51 \mathrm{ng} / \mathrm{ml}, 3.36+/-2.07 \mathrm{ng} / \mathrm{ml}$, and $8.02+/-$ $7.81 \mathrm{ng} / \mathrm{ml}$ in each group, respectively. Thus, NSCLC cfDNA appears to be primarily from tumor development and not inflammation. Interestingly, LC cfDNA levels also have prognostic value, as patients with lower LC cfDNA levels are less likely to progress. A recent meta-analysis of 22 studies involving 2,581 patients revealed that higher LC cfDNA levels correlated with shorter progression-free and over-all survivals [45-48]. Further studies are required to analyze tumor cfDNA size, origin, possible functions, and clinical uses [27-30].

\section{cfDNA Preparation}

cfDNA is usually obtained by phlebotomy and should be processed rapidly due to its short half-life $[49,50]$. Often blood is collected into an EDTA tube (Vacutainer), which prevents clotting and inhibits DNase I activity [51]. Plasma is most often used as clotting releases benign leukocyte DNA, diluting tumor cfDNA [52]. This DNA can be purified by several different methods, with the QIAamp DNA Blood Mini Kit (Qiagen) commonly 
Table 2: A summary of the more commonly used techniques to analyze cfDNA. The different techniques are described, and the specific advantages and disadvantages, and relative costs of each technique are briefly summarized.

\begin{tabular}{|c|c|c|c|c|}
\hline \multicolumn{2}{|c|}{ Analysis Technique } & \multirow{2}{*}{$\begin{array}{l}\text { Advantages } \\
\text { Low cost, relatively easily } \\
\text { implemented. }\end{array}$} & \multirow{2}{*}{$\begin{array}{l}\text { Disadvantages } \\
\text { Low sensitivity } \\
\text { for cfDNA, only } \\
\text { interrogates DNA for } \\
\text { areas between the } \\
\text { primer sequences. }\end{array}$} & \multirow{2}{*}{$\begin{array}{l}\text { Refs } \\
\\
{[56-} \\
58]\end{array}$} \\
\hline $\begin{array}{l}\text { Conventional } \\
\text { Real-Time } \\
\text { qPCR }\end{array}$ & $\begin{array}{l}\text { DNA is amplified by repeated cycles } \\
\text { of DNA, primer, and probe thermal } \\
\text { denaturation, annealing, and DNA } \\
\text { polymerization with a heat-tolerant } \\
\text { DNA polymerase. }\end{array}$ & & & \\
\hline $\begin{array}{l}\text { Scorpion } \\
\text { ARMS PCR }\end{array}$ & $\begin{array}{l}\text { A bi-functional PCR primer covalently } \\
\text { linked to a probe with closely } \\
\text { associated fluorophore and a quencher. } \\
\text { Amplification will only happen if } \\
\text { the 3' primer nucleotides match the } \\
\text { target sequence. During the PCR } \\
\text { reaction, the fluorophore and quencher } \\
\text { become separate, giving a detectable } \\
\text { fluorescence. }\end{array}$ & $\begin{array}{l}\text { Relatively low cost and high } \\
\text { sensitivity. }\end{array}$ & $\begin{array}{l}\text { Only identifies the } \\
\text { specific sequences the } \\
\text { probes are designed to } \\
\text { detect. }\end{array}$ & $\begin{array}{l}{[59-} \\
61]\end{array}$ \\
\hline $\begin{array}{l}\text { PNA-LNA } \\
\text { PCR }\end{array}$ & $\begin{array}{l}\text { Composed of an uncharged polyamide } \\
\text { backbone with attached bases that } \\
\text { hybridizes to ssDNA with high affinity } \\
\text { allowing probes enhanced binding to } \\
\text { dilute cfDNA sequences than standard } \\
\text { PCR DNA probes. }\end{array}$ & High sensitivity, lower cost. & $\begin{array}{l}\text { Only identifies the } \\
\text { specific sequences the } \\
\text { probes are designed to } \\
\text { detect. }\end{array}$ & $\begin{array}{l}{[62],} \\
{[63]}\end{array}$ \\
\hline NGS & $\begin{array}{l}\text { DNA is fragmented into millions } \\
\text { of short segments, ligated to DNA } \\
\text { adaptor molecules, segregated on a } \\
\text { solid matrix, and sequenced in parallel } \\
\text { by labeled nucleotides addition, } \\
\text { and bioinformatically aligned into a } \\
\text { genomic sequence. }\end{array}$ & $\begin{array}{l}\text { Can target specific } \\
\text { sequences, the exome, entire } \\
\text { genome, detect all sequence } \\
\text { variations, rearrangements, } \\
\text { copy number changes, and } \\
\text { often gene fusions. }\end{array}$ & $\begin{array}{l}\text { High cost, complex to } \\
\text { implement, analysis } \\
\text { complex and requires } \\
\text { bioinformatics } \\
\text { analysis. }\end{array}$ & $\begin{array}{l}{[19],} \\
{[64-} \\
66]\end{array}$ \\
\hline $\mathrm{dPCR}$ & $\begin{array}{l}\text { Partitions cfDNA into thousands of } \\
\text { parallel individual PCR reactions. } \\
\text { Signal detection means the target } \\
\text { sequence is present. }\end{array}$ & $\begin{array}{l}\text { High sensitivity, can } \\
\text { analyze multiple analytes } \\
\text { simultaneously. }\end{array}$ & $\begin{array}{l}\text { Only identifies the } \\
\text { specific sequences the } \\
\text { probes are designed to } \\
\text { detect. }\end{array}$ & $\begin{array}{l}{[67],} \\
{[68]}\end{array}$ \\
\hline
\end{tabular}

used [53]. Newer techniques are being developed to improve cfDNA isolation and preservation. For example, Jeon et al. [54] developed a free-standing 3D array of gold nanowires coated with a conducting polymer which could recover $\geq 10 \mathrm{pg} / \mathrm{mL}$ lung and breast cancer cfDNA with a high yield and purity.

\section{cfDNA Analysis Techniques}

Tumor cfDNA is prepared and subsequently analyzed by a variety of techniques, some of which can interrogate the entire exome or genome, while others target specific genes. Each technique has specific advantages and disadvantages, and includes digital PCR (dPCR), scorpion amplification refractory mutation system (ARMS), peptide nucleic acid-locked clamp PCR (PNA-LNA), next generation DNA sequencing methods
(NGS), and epigenetic analyses. Tumor cfDNA analysis can be challenging as it can make up as little as $0.01 \%$ of the total cfDNA pool. Tumor cfDNA can be present at low $\mathrm{ng} / \mathrm{ml}$ concentrations, is less stable than non-tumor cfDNA, and is often degraded [27-36,41-43,47,48,55]. Additionally only $0.004 \%$ of the LC genome is regularly mutated, making the relevant fraction of cfDNA to be analyzed quite small [55]. Several of the more common cfDNA analysis techniques and their advantages and disadvantages are summarized in Table 2.

\section{APPLICATIONS OF CFDNA LC ANALYSIS AND TREATMENT}

cfDNA analysis has multiple applications in LC treatment, including analyzing tumor molecular heterogeneity, monitoring disease burden and prognosis, 
and the early detection of emerging therapy resistance. Here we will briefly discuss these analyses.

\section{cfDNA and Tumor Molecular Heterogeneity}

Alegre et al. [69] used dPCR to analyze EGFR mutation positive cfDNA in LC patients being treated with EGFR inhibitors. Interestingly, dPCR cfDNA EGFR analysis revealed EGFR mutations not detected by tumor biopsy analysis in $34 \%$ of patients examined. Although a single study with a low $(N=36)$ patient number, it indicates that the liquid biopsy can reveal information about tumor molecular heterogeneity not found by tissue biopsy.

\section{cfDNA and lung cancer disease burden monitoring and prognosis}

KRAS mutation positive pulmonary AdenoCAs are presently not treatable, although targeted therapies are being developed [70]. KRAS mutation positive tumors often have a poor prognosis and are associated with a high mutation burden [72]. Guibert et al. [71] used dPRC to serially analyze KRAS positive AdenoCA cfDNA in 34 patients with tumors carrying KRAS mutations identified by tumor tissue PCR analyses. Patients who progressed had an initial average cfDNA level of 947 KRAS mutated alleles $/ \mathrm{ml}$, while those whose disease was controlled averaged 147/ml. Additionally, higher mutated KRAS cfDNA allele levels correlated with poor therapy responses (71).

Sozzi et al. [73] analyzed 43 healthy individuals and 84 NSCLC patients and found that plasma cfDNA was higher in NSCLC patients (including stage I patients) with an average of $318 \mathrm{ng} / \mathrm{ml}$ compared to $18 \mathrm{ng} / \mathrm{ml}$ in healthy controls. Where follow-up was performed, NSCLC patients' cfDNA averaged $345 \mathrm{ng} / \mathrm{ml}$ before tumor resection and fell to $34 \mathrm{ng} / \mathrm{ml}$ post-surgery. cfDNA showed a trend towards reduction in relapse-free patients, but showed a 2-20-fold increases in relapsed patients. In a later study, 1,035 heavy smokers were followed for 5-years with spiral CT combined with plasma DNA PCR analysis [46]. Of 38 individuals who developed LC, higher plasma cfDNA was associated with a poorer 5 -year survival.

Newman et al. [55] used the CAPP-Seq technique to quantify cfDNA in NSCLC patients and compared cfDNA levels to CT and PET tumor imaging. cfDNA levels significantly correlated with $\mathrm{CT}$ and PET measured tumor volume $\left(\mathrm{R}^{2}=0.89, P=0.0002\right)$. In the same study, 3 patients' cfDNA was followed during NSCLC therapy and lower or higher cfDNA plasma concentrations correlated with better or worse outcomes, respectively. While other studies have failed to show a correlation between cfDNA concentrations and PET-measured tumor volumes, it appears that careful cfDNA analysis correlates with LC tumor burden and can have prognostic value $[46,55,71$, 72].

Activating EGFR receptor mutations are found in about $15 \%$ of lung AdenoCAs, $90 \%$ of which are either the L858R point mutation or in-frame deletions of exon 19 [5, 6, 75-77]. These AdenoCAs are often treated with erlotinib, gefitinib, or afatinib $[5,6]$. Most patients receiving these drugs will develop drug resistance within one year. Approximately $50 \%$ of this resistance is due to EGFR T790M mutation emergence [78]. Some evidence indicates that T790M may be present at low levels in EGFR mutated AdenoCAs prior to EGFR drug therapy [79, 80]. Wang et al. [81] used dPCR and ARMS to analyze T790M cfDNA mutations in 135 TKI-treated lung AdenoCAs patients who had progression-free survival on the TKIs for over six months. APCR and ARMS identified $\mathrm{T} 790 \mathrm{M}$ in $31.3 \%$ and $5.5 \%$ of patients prior to TKI therapy, respectively, demonstrating that $\mathrm{dPCR}$ was a more sensitive test. Post TKI therapy, the same tests showed $\mathrm{T} 790 \mathrm{M}$ in $43.0 \%$ and $25.2 \%$ of patients, respectively. Patients with high pre-TKI therapy T790M levels had a poorer progression-free and overall survival, demonstrating prognostic value.

\section{cfDNA and lung cancer therapy resistance monitoring}

Sorensen et al. [82] used allele-specific PCR to quantify 42 different erlotinib-sensitive EGFR mutations in the plasma of 23 patients with advanced AdenoCAs. Sampling was performed before erlotinib treatment and then done sequentially with erlotinib treatment. Ninetysix percent $(22 / 23)$ of patients showed a reduction in the sensitizing mutations (L858R or ex19Del) upon erlotinib treatment initiation. Initially no patients carried the T790M mutation. With treatment, $39 \%$ of the patients developed the $\mathrm{T} 790 \mathrm{M}$ mutation with a concomitant increase in erlotinib-sensitive EGFR mutations. Interestingly, T790M elevations appeared up to 344 days before clinical LC progression was evident (range 15-344 days). Thus, serial monitoring for T790M may allow the earlier detection of resistance-related LC progression. Detecting T790M is also important as the TKI TAGRISSO is now used clinically to target T790M positive NSCLC [83].

Miyazawa et al. [63] used a PNA-LNA probe to examine T790M in 151 gefitinib-treated NSCLC from 17 sputums, 63 bronchial washings, 3 transbronchial biopsies, 4 needle aspiration biopsies, 17 pleural effusions, and 1 pericardial effusion. Initially no patients carried T790M, but 4 patients who became resistant to gefitinib developed T790M. Oxnard et al. [84] used dPCR to examine cfDNA in patients with advanced NSCLC carrying exon 19 deletions treated with erlotinib. Nine patients without an initial T790M mutation were treated with erlotinib and 8 
had a complete "plasma response", or a complete loss of mutant EGFR cfDNA. In 6 patients the cfDNA exon 19 deletion EGFR mutation concomitantly rose with T790M 4-12 weeks prior to RECIST progression. The remaining patients had indolent asymptomatic progression in the chest only and remained on erlotinib. Further, Watanabe et al. [85] examined 373 NSCLC patient tumor samples with EGFR-activating mutations for T790M via ultra-sensitive dPCR. T790M was found in $79.9 \%$ of the patients and the mutation was associated with larger tumor volumes. This data, combined with the previously cited studies, indicates that LC often carries T790M and cfDNA analysis may have value in monitoring disease burden, disease progression, and drug resistance emergence [83].

\section{CTCs}

First identified by autopsy in 1869, CTCs arise from solid tumors and circulate in the blood and/or lymphatic vessels [86]. CTCs are heterogeneous cell populations that circulate as single cells or as tumor cell clusters, and are assumed to contain subpopulations with metastatic potential or the ability to re-circulate back to the tumor (termed "tumor self-seeding/cross seeding") [86-90]. High baseline CTCs concentrations at initial diagnosis and/or high CTCs following one cycle of chemotherapy confer a poor LC prognosis [91-94]. LC CTCs may increase at higher tumor stages and are often higher in SCLC than in NSCLC $[92,95]$. Measurements using murine models indicate that for each gram of tumor, about $10^{6}$ CTCs are released per day [96]. Despite this, CTC blood concentrations are often low at 1-10 CTCs per ml of blood, which contains $10^{6}-10^{7}$ white cells [91-96]. Additionally, several studies of LC patients' CTCs revealed that in 15 $70 \%$ of LC patients CTCs are not detectable $[55,56,58]$.

Due to their low concentrations, CTC analysis often requires an initial enrichment step. While there are many different enrichment techniques, they often employ isolation either based on cell-specific surface markers (CD45-, EpCAM+, and cytokeratins 8, 18, and/or 19) or features often unique to CTCs, such as a larger size ( $10 \mu \mathrm{m}$ for leukocytes vs. $15 \mu \mathrm{m}$ for many CTCs) [97100]. Detecting EpCAM+ CTCs in NSCLC is likely to miss many CTCs, as NSCLC CTCs undergo an epithelialmesenchymal transformation becoming EpCAM- and vimentin $+[91,101,102]$. Farace et al. [101] examined the abilities of the CellSearch and Isolation by SizE of Tumor cells (ISET) CTC isolation systems to detect NSCLC CTCs in the blood of 20 patients. The CellSearch isolates EpCAM+, CD45- CTCs, while Isolation by ISET isolates CTCs based on cell size. The two methods had a low $20 \%$ concordance, indicating isolating EpCAM+ NSCLC CTCs may miss many CTCs. Other studies revealed that size filtration followed by cytologic characterization gave a more efficient NSCLC CTC isolation, allowing the detection of EML-ALK and ROS1 rearrangements in CTCs $[94,103,104]$. Other CTC isolation techniques include CTC microchips, automated microscopy systems, enzyme-linked epithelial immunospot assays, and reversetranscriptase PCR [101, 105-108]. Recently CTC isolation techniques have been developed that can isolate CTCs at very low concentrations. For example, Yoon et al. [109] used functionalized graphene oxide nanosheets on a patterned gold surface to capture CTCs at 3-5 cells $/ \mathrm{ml}$ with $73 \%$ efficiency. Due to the often low CTC cell yield, cell numbers have been increased by in vitro culture or engrafted into immunocompromised mice, increasing the sample volume for analysis $[110,111]$.

Once isolated LC CTCs can be analyzed like other pulmonary tissue. Maheswaran et al. [112] used a microfluidic device containing microposts coated with antibodies against epithelial cells followed by allelespecific polymerase-chain-reaction EGFR mutation amplification in NSCLC patients. L858R, del 19, and T790M mutations were detected in the CTCs. Interestingly patients who were pretreatment-positive for T790M CTCs had a progression-free survival of 7.7 months vs. 16.5 for those who were initially T790M negative. Additionally, serial analysis of CTCs revealed that CTC levels correlate with the radiographic tumor response and increasing CTCs were associated with tumor progression and in some cases the emergence of new EGFR mutations. Aieta et al. [113] followed EML-ALK levels in a NSCLC patient's CTCs and found a CTC reduction upon successful crizotinib treatment. Similarly, Ilie et al. [114] examined 87 lung AdenoCA patients by ALK FISH analysis and found 5 cases positive by both tissue biopsy and CTC analysis. Lastly, Guibert et al. [115] detected KRAS mutations by dPCR in $34 \%$ of CTCs in 32 NSCLC patients. In the same study, cfDNA analysis allowed detection in $82 \%$ of the same patients, demonstrating the superior sensitivity of cfDNA analysis. These studies demonstrate that CTC analysis can guide LC therapy, monitor treatment resistance emergence, and provide prognostic information. Currently there have been nearly 400 clinical trials examining LC CTCs, but so far, LC CTCs are rarely used in clinical practice (see "ClinicalTrials.gov").

\section{TEPs}

At all times approximately $75-200 \times 10^{10}$ platelets circulate in the bloodstream of healthy individuals, making them the second most abundant peripheral formed blood element [116]. Platelets play a central role in thrombosis and wound healing, and regulate systemic and local responses to malignancy [117]. Tumor cells can transfer tumor-associated biomolecules to platelets, an event termed "tumor education" As a result platelet RNA and protein profiles are altered to promote tumor growth and increase tumor metastatic potential [117, 118]. Best et al. [117] used RNA sequencing to analyze 283 patient platelet samples from 55 healthy individuals and 228 patients with NSCLC, glioblastoma, colon, pancreatic, hepatobiliary, and breast cancers. The analysis was $96 \%$ 
accurate in distinguishing healthy individuals from those with cancer, $71 \%$ accurate in identifying the specific cancer subtypes, and correctly identified EGFR, KRAS, and PIK3CA mutations.

Nilsson et al. [118] analyzed 77 NSCLC patients, 32 of whom carried EML-ALK fusions. RT-PCR of platelet RNA had $65 \%$ sensitivity and $100 \%$ specificity for EMLALK detection. Interestingly, analysis of circulating RNAs in the same patients had a $21 \%$ sensitivity and $100 \%$ specificity, likely reflecting lower RNA stability in the latter samples. In a 29 patient subset treated with crizotinib, progression-free survival was 3.7 months in individuals with EML-ALK+ platelets and 16 months for those with EML-ALK- platelets. Several crizotinib-treated patients initially EML-ALK + became negative following treatment and one patient serially followed over 30 months showed crizotinib-resistance measured by increased platelet EML-ALK 2 months before progression was detected by PET-CT. Although preliminary, these studies indicate that TEPs may be useful in LC diagnostics, particularly as they are more abundant than CTCs [119].

\section{TECs}

TECs line tumor blood vessels and are morphologically and biochemically distinct from normal endothelial cells (ECs). They often show unusual tortuous shapes and a chaotic organization not seen in benign tissues. TECs can have projections that extend into the vessel lumen and impair normal barrier functions, allowing the leakage and pooling of erythrocytes [121]. TECs show radically different gene expression patterns than ECs in non-cancerous tissues. For example, Maishi et al. [25] reported a role for TECs in tumor metastasis, demonstrating a bidirectional crosstalk between tumor cells and TECs that regulated tumor metastasis. Using a murine cancer model, TECs isolated from highly metastatic tumors, accelerated metastasis when implanted in animals with low metastatic potential tumors. Molecular analysis of the TECs promoting metastasis revealed decreased biglycan promoter methylation with increased biglycan expression. Biglycan activates both NF- $\kappa \mathrm{B}$ and extracellular signal-regulated kinase $1 / 2$ in the tumor cells, promoting metastasis. Examination of the PrognoScan database, a large collection of publicly available cancer microarray datasets with clinical correlation, revealed increased biglycan levels correlate with increased metastasis in human tumors, including LC [25]. TECs will require extensive research before having clinical applications, however present data supports a role for them in tumor metastasis.

\section{ES}

ES are released by exocytosis and consist of membranous particles occurring in many body fluids, including blood, ascites, and pleural effusions [123-125]. Two classes of ES have been identified; exosomes (30-
$120 \mathrm{~nm})$ and microvesicles $\left(100-10^{3} \mathrm{~nm}\right)$. ES are enriched for several proteins, and contain mRNA, miRNA, tRNA, ssDNA, mitochondrial DNA, and dsDNA [125, 126]. Tumor-released ES appear to facilitate tumor growth by activating benign cells towards tumor growthpromoting phenotypes [127]. NSCLC secretes ES and Lin et al. [128] demonstrated that the miRNA patterns are different between the pleural effusions in pulmonary tuberculosis, pneumoniae, and NSCLC, making them clinically distinguishable [128-130]. Sandfeld-Paulsen et al. [130] examined ES in 276 NSCLC patients captured with antibodies to general ES marker proteins. Fortynine proteins attached to the exosomal membranes were evaluated based on their presence and concentration, and correlated with over-all patient survival. Of the 49 proteins, increased NY-ESO-1 was present in 50\% of the patients and was a highly significant inferior survival prognostic biomarker. Brinkmann et al. [131] purified ES RNA from NSCLC patients and subjected it to RT-qPCR for EML4-ALK transcripts. EML4-ALK transcripts were detected in $70 \%$ of cases known to carry the fusion by previous tissue biopsy analysis. Similarly Krug et al. [132] used NGS to analyze activating EGFR mutations and the T790M EGFR mutations in blood ES from 54 NSCLC patients who had these mutations previously identified by tumor tissue analysis. A 96\% concordance between the tumor biopsy results and ES and cfDNA NGS results was found for the activating EGFR mutations and $86 \%$ for the T790M mutation. Taken together these results indicate that ES analysis may have value in LC diagnostics.

\section{CONCLUSIONS AND FUTURE DIRECTIONS}

Liquid biopsy approaches hold great potential in LC cancer diagnostics. cfDNA, CTCs, TEPs, TECs, and tumor ES all show promise, although few are currently used clinically [25-48, 69-81,112-115,117-119,128132]. Presently several challenges must be met before the liquid biopsy can enter clinical practice, including 1) optimizing and standardizing sample gathering, 2) implementing uniform analytical procedures, 3) identifying the circulating analyte(s) most likely to yield useful information, and 4) performing the sufficiently large multi-center clinical trials necessary for validating specific analysis protocols [133]. Additionally, as many circulating analytes occur at low concentrations or are "rare events", maximizing test sensitivity will be a challenge. Protocols such as those employed by Newman et al. [55], which increases assay sensitivity by targeting the specific mutations within LC, will likely prove useful. With time, the technical challenges of the liquid biopsy will likely be solved and it will become an important tool in LC diagnostics and treatment. 


\section{CONFLICTS OF INTEREST}

The authors confirm that there are no conflicts of interest.

\section{REFERENCES}

1. Torre LA, Siegel RL, Ward EM and Jemal A. Global Cancer Incidence and Mortality Rates and Trends-An Update. Cancer Epidemiol Biomarkers Prev. 2016; 25: 16-27.

2. Bruske-Hohlfeld I. Environmental and occupational risk factors for lung cancer. Methods Mol Biol. 2009; 472: 3-23.

3. Marcus PM, Bergstralh EJ, Fagerstrom RM, Williams DE, Fontana R, Taylor WF and Prorok PC. Lung cancer mortality in the Mayo Lung Project: impact of extended follow-up. J Natl Cancer Inst. 2000; 92: 1308-1316.

4. Aberle DR, Adams AM, Berg CD, Black WC, Clapp JD, Fagerstrom RM, Gareen IF, Gatsonis C, Marcus PM, Sicks JD and Team NLSTR. Reduced lung-cancer mortality with low-dose computed tomographic screening. N Engl J Med. 2011; 365: 395-409.

5. Gerber DE, Paik PK and Dowlati A. Beyond adenocarcinoma: current treatments and future directions for squamous, small cell, and rare lung cancer histologies. Am Soc Clin Oncol Educ Book. 2015: 147-162.

6. Wu YL, Zhou C, Hu CP, Feng J, Lu S, Huang Y, Li W, Hou M, Shi JH, Lee KY, Xu CR, Massey D, Kim M, Shi Y and Geater SL. Afatinib versus cisplatin plus gemcitabine for first-line treatment of Asian patients with advanced nonsmall-cell lung cancer harbouring EGFR mutations (LUXLung 6): an open-label, randomised phase 3 trial. Lancet Oncol. 2014; 15: 213-222.

7. Thomas A, Liu SV, Subramaniam DS and Giaccone G. Refining the treatment of NSCLC according to histological and molecular subtypes. Nat Rev Clin Oncol. 2015; 12: 511-526.

8. Shackelford RE, Vora M, Mayhall K and Cotelingam J. ALK-rearrangements and testing methods in non-small cell lung cancer: a review. Genes Cancer. 2014; 5: 1-14.

9. Solomon BJ, Mok T, Kim DW, Wu YL, Nakagawa K, Mekhail T, Felip E, Cappuzzo F, Paolini J, Usari T, Iyer S, Reisman A, Wilner KD, Tursi J, Blackhall $\mathrm{F}$ and Investigators P. First-line crizotinib versus chemotherapy in ALK-positive lung cancer. N Engl J Med. 2014; 371: 2167 2177.

10. Shaw AT, Ou SH, Bang YJ, Camidge DR, Solomon BJ, Salgia R, Riely GJ, Varella-Garcia M, Shapiro GI, Costa DB, Doebele RC, Le LP, Zheng Z, Tan W, Stephenson P, Shreeve SM, et al. Crizotinib in ROS1-rearranged nonsmall-cell lung cancer. N Engl J Med. 2014; 371: 19631971.

11. Hyman DM, Puzanov I, Subbiah V, Faris JE, Chau I, Blay JY, Wolf J, Raje NS, Diamond EL, Hollebecque A, Gervais R, Elez-Fernandez ME, Italiano A, Hofheinz RD, Hidalgo
M, Chan E, et al. Vemurafenib in Multiple Nonmelanoma Cancers with BRAF V600 Mutations. N Engl J Med. 2015; 373: 726-736.

12. Brock MV, Hooker CM, Ota-Machida E, Han Y, Guo M, Ames S, Glöckner S, Piantadosi S, Gabrielson E, Pridham G, Pelosky K, Belinsky SA, Yang SC, Baylin SB and Herman JG. DNA methylation markers and early recurrence in stage I lung cancer. N Engl J Med. 2008; 358(: 11181128.

13. Ansari J, Shackelford RE and El-Osta H. Epigenetics in non-small cell lung cancer: from basics to therapeutics. Transl Lung Cancer Res. 2016; 5: 155-171.

14. Hochhegger B, Alves GR, Irion KL, Fritscher CC, Fritscher LG, Concatto NH, Marchiori E. PET/CT imaging in lung cancer: indications and findings. J Bras Pneumol. 2015; 41; 264-274.

15. Murtaza M, Dawson SJ, Tsui DW, Gale D, Forshew T, Piskorz AM, Parkinson C, Chin SF, Kingsbury Z, Wong AS, Marass F, Humphray S, Hadfield J, Bentley D, Chin TM, Brenton JD, et al. Non-invasive analysis of acquired resistance to cancer therapy by sequencing of plasma DNA. Nature. 2013; 497: 108-112.

16. Vanderlaan PA, Yamaguchi N, Folch E, Boucher DH, Kent MS, Gangadharan SP, Majid A, Goldstein MA, Huberman MS, Kocher ON and Costa DB. Success and failure rates of tumor genotyping techniques in routine pathological samples with non-small-cell lung cancer. Lung Cancer. 2014; 84: 39-44.

17. Kim ES, Hirsh V, Mok T, Socinski MA, Gervais R, Wu YL, Li LY, Watkins CL, Sellers MV, Lowe ES, Sun Y, Liao ML, Osterlind K, Reck M, Armour AA, Shepherd FA, et al. Gefitinib versus docetaxel in previously treated non-smallcell lung cancer (INTEREST): a randomised phase III trial. Lancet. 2008; 372: 1809-1818.

18. Mok TS, Wu YL, Thongprasert S, Yang CH, Chu DT, Saijo N, Sunpaweravong P, Han B, Margono B, Ichinose Y, Nishiwaki Y, Ohe Y, Yang JJ, Chewaskulyong B, Jiang H, Duffield EL, et al. Gefitinib or carboplatin-paclitaxel in pulmonary adenocarcinoma. N Engl J Med. 2009; 361: 947957.

19. Gerlinger M, Rowan AJ, Horswell S, Larkin J, Endesfelder D, Gronroos E, Martinez P, Matthews N, Stewart A, Tarpey P, Varela I, Phillimore B, Begum S, McDonald NQ, Butler A, Jones D, et al. Intratumor heterogeneity and branched evolution revealed by multiregion sequencing. $\mathrm{N}$ Engl $\mathrm{J}$ Med. 2012; 366: 883-892.

20. Zhang Z, Ramnath N and Nagrath S. Current Status of CTCs as Liquid Biopsy in Lung Cancer and Future Directions. Front Oncol. 2015; 5: 209.

21. Pietras K and Ostman A. Hallmarks of cancer: interactions with the tumor stroma. Exp Cell Res. 2010; 316: 13241331.

22. Azmi AS, Bao B and Sarkar FH. Exosomes in cancer development, metastasis, and drug resistance: a 
comprehensive review. Cancer Metastasis Rev. 2013; 32: 623-642.

23. Diaz LA, Williams RT, Wu J, Kinde I, Hecht JR, Berlin J, Allen B, Bozic I, Reiter JG, Nowak MA, Kinzler KW, Oliner KS and Vogelstein B. The molecular evolution of acquired resistance to targeted EGFR blockade in colorectal cancers. Nature. 2012; 486: 537-540.

24. McAllister SS and Weinberg RA. The tumour-induced systemic environment as a critical regulator of cancer progression and metastasis. Nat Cell Biol. 2014; 16: 717727.

25. Maishi N, Ohba Y, Akiyama K, Ohga N, Hamada J, NagaoKitamoto H, Alam MT, Yamamoto K, Kawamoto T, Inoue N, Taketomi A, Shindoh M, Hida Y and Hida K. Tumour endothelial cells in high metastatic tumours promote metastasis via epigenetic dysregulation of biglycan. Sci Rep. 2016; 6: 28039.

26. Mandel P, Metais P. C R Seances Soc Biol Fil. 1948; 142: 241-243.

27. Giacona MB, Ruben GC, Iczkowski KA, Roos TB, Porter DM and Sorenson GD. Cell-free DNA in human blood plasma: length measurements in patients with pancreatic cancer and healthy controls. Pancreas. 1998; 17: 89-97.

28. Stroun M, Lyautey J, Lederrey C, Olson-Sand A and Anker P. About the possible origin and mechanism of circulating DNA apoptosis and active DNA release. Clin Chim Acta. 2001; 313: 139-142.

29. Fan HC, Blumenfeld YJ, Chitkara U, Hudgins L and Quake SR. Analysis of the size distributions of fetal and maternal cell-free DNA by paired-end sequencing. Clin Chem. 2010; 56: 1279-1286.

30. Mouliere F, Robert B, Arnau Peyrotte E, Del Rio M, Ychou M, Molina F, Gongora C and Thierry AR. High fragmentation characterizes tumour-derived circulating DNA. PLoS One. 2011; 6: e23418.

31. Thierry AR, Mouliere F, Gongora C, Ollier J, Robert B, Ychou M, Del Rio M and Molina F. Origin and quantification of circulating DNA in mice with human colorectal cancer xenografts. Nucleic Acids Res. 2010; 38: 6159-6175.

32. Agostini M, Enzo MV, Bedin C, Belardinelli V, Goldin E, Del Bianco P, Maschietto E, D’Angelo E, Izzi L, Saccani A, Zavagno G and Nitti D. Circulating cell-free DNA: a promising marker of regional lymphonode metastasis in breast cancer patients. Cancer Biomark. 2012; 11: 89-98.

33. Wang BG, Huang HY, Chen YC, Bristow RE, Kassauei K, Cheng CC, Roden R, Sokoll LJ, Chan DW and Shih Ie M. Increased plasma DNA integrity in cancer patients. Cancer Res. 2003; 63: 3966-3968.

34. Jiang WW, Zahurak M, Goldenberg D, Milman Y, Park HL, Westra WH, Koch W, Sidransky D and Califano J. Increased plasma DNA integrity index in head and neck cancer patients. Int J Cancer. 2006; 119: 2673-2676.

35. Stroun M, Maurice P, Vasioukhin V, Lyautey J, Lederrey C,
Lefort F, Rossier A, Chen XQ and Anker P. The origin and mechanism of circulating DNA. Ann N Y Acad Sci. 2000; 906: 161-168.

36. Leon SA, Shapiro B, Sklaroff DM and Yaros MJ. Free DNA in the serum of cancer patients and the effect of therapy. Cancer Res. 1977; 37: 646-650.

37. Garcia-Olmo DC, Dominguez C, Garcia-Arranz M, Anker P, Stroun M, Garcia-Verdugo JM and Garcia-Olmo D. Cellfree nucleic acids circulating in the plasma of colorectal cancer patients induce the oncogenic transformation of susceptible cultured cells. Cancer Res. 2010; 70: 560-567.

38. Garcia-Olmo D, Garcia-Olmo DC, Ontanon J, Martinez E and Vallejo M. Tumor DNA circulating in the plasma might play a role in metastasis. The hypothesis of the genometastasis. Histol Histopathol. 1999; 14: 1159-1164.

39. Trejo-Becerril C, Perez-Cardenas E, Taja-Chayeb L, Anker P, Herrera-Goepfert R, Medina-Velazquez LA, Hidalgo-Miranda A, Perez-Montiel D, Chavez-Blanco A, Cruz-Velazquez J, Diaz-Chavez J, Gaxiola M and DuenasGonzalez A. Cancer progression mediated by horizontal gene transfer in an in vivo model. PLoS One. 2012; 7: e52754.

40. Jiang $\mathrm{P}$, Chan $\mathrm{CW}$, Chan $\mathrm{KC}$, Cheng SH, Wong J, Wong VW, Wong GL, Chan SL, Mok TS, Chan HL, Lai PB, Chiu RW and Lo YM. Lengthening and shortening of plasma DNA in hepatocellular carcinoma patients. Proc Natl Acad Sci U S A. 2015; 112: E1317-1325.

41. Fleischhacker $M$ and Schmidt B. Circulating nucleic acids (CNAs) and cancer-a survey. Biochim Biophys Acta. 2007; 1775: 181-232.

42. Stroun M, Anker P, Maurice P, Lyautey J, Lederrey C and Beljanski M. Neoplastic characteristics of the DNA found in the plasma of cancer patients. Oncology. 1989; 46: 318322.

43. Diehl F, Schmidt K, Choti MA, Romans K, Goodman S, Li M, Thornton K, Agrawal N, Sokoll L, Szabo SA, Kinzler KW, Vogelstein B and Diaz LA, Jr. Circulating mutant DNA to assess tumor dynamics. Nat Med. 2008; 14: 985-990.

44. Fournie GJ, Courtin JP, Laval F, Chale JJ, Pourrat JP, Pujazon MC, Lauque D and Carles P. Plasma DNA as a marker of cancerous cell death. Investigations in patients suffering from lung cancer and in nude mice bearing human tumours. Cancer Lett. 1995; 91: 221-227.

45. Paci M, Maramotti S, Bellesia E, Formisano D, Albertazzi L, Ricchetti T, Ferrari G, Annessi V, Lasagni D, Carbonelli C, De Franco S, Brini M, Sgarbi G and Lodi R. Circulating plasma DNA as diagnostic biomarker in non-small cell lung cancer. Lung Cancer. 2009; 64: 92-97.

46. Sozzi G, Conte D, Mariani L, Lo Vullo S, Roz L, Lombardo C, Pierotti MA and Tavecchio L. Analysis of circulating tumor DNA in plasma at diagnosis and during follow-up of lung cancer patients. Cancer Res. 2001; 61: 4675-4678.

47. Szpechcinski A, Chorostowska-Wynimko J, Struniawski R, Kupis W, Rudzinski P, Langfort R, Puscinska E, Bielen 
P, Sliwinski P and Orlowski T. Cell-free DNA levels in plasma of patients with non-small-cell lung cancer and inflammatory lung disease. Br J Cancer. 2015; 113: 476483.

48. Tissot C, Toffart AC, Villar S, Souquet PJ, Merle P, MoroSibilot D, Perol M, Zavadil J, Brambilla C, Olivier M and Couraud S. Circulating free DNA concentration is an independent prognostic biomarker in lung cancer. Eur Respir J. 2015; 46: 1773-1780.

49. Sarioglu AF, Aceto N, Kojic N, Donaldson MC, Zeinali M, Hamza B, Engstrom A, Zhu H, Sundaresan TK, Miyamoto DT, Luo X, Bardia A, Wittner BS, Ramaswamy S, Shioda T, Ting DT, et al. A microfluidic device for label-free, physical capture of circulating tumor cell clusters. Nat Methods. 2015; 12: 685-691.

50. Ntouroupi TG, Ashraf SQ, McGregor SB, Turney BW, Seppo A, Kim Y, Wang X, Kilpatrick MW, Tsipouras P, Tafas T and Bodmer WF. Detection of circulating tumour cells in peripheral blood with an automated scanning fluorescence microscope. Br J Cancer. 2008; 99: 789-795.

51. Barra GB, Santa Rita TH, de Almeida Vasques J, Chianca CF, Nery LF and Santana Soares Costa S. EDTA-mediated inhibition of DNases protects circulating cell-free DNA from ex vivo degradation in blood samples. Clin Biochem. 2015; 48: 976-981.

52. Chan KC, Yeung SW, Lui WB, Rainer TH and Lo YM. Effects of preanalytical factors on the molecular size of cell-free DNA in blood. Clin Chem. 2005; 51: 781-784.

53. Chan KC, Yeung SW, Lui WB, Rainer TH and Lo YM. Effects of preanalytical factors on the molecular size of cell-free DNA in blood. Clin Chem. 2005; 51: 781-784.

54. Jeon S, Lee H, Bae K, Yoon KA, Lee ES and Cho Y. Efficient Capture and Isolation of Tumor-Related Circulating Cell-Free DNA from Cancer Patients Using Electroactive Conducting Polymer Nanowire Platforms. Theranostics. 2016; 6: 828-836.

55. Newman AM, Bratman SV, To J, Wynne JF, Eclov NC, Modlin LA, Liu CL, Neal JW, Wakelee HA, Merritt RE, Shrager JB, Loo BW, Jr., Alizadeh AA and Diehn M. An ultrasensitive method for quantitating circulating tumor DNA with broad patient coverage. Nat Med. 2014; 20: 548554.

56. Xu Q, Zhu Y, Bai Y, Wei X, Zheng X, Mao M and Zheng G. Detection of epidermal growth factor receptor mutation in lung cancer by droplet digital polymerase chain reaction. Onco Targets Ther. 2015; 8: 1533-1541.

57. Nielsen PE, Egholm $\mathrm{M}$, Berg RH and Buchardt $\mathrm{O}$. Sequence-selective recognition of DNA by strand displacement with a thymine-substituted polyamide. Science. 1991; 254: 1497-1500.

58. Miyazawa H, Tanaka T, Nagai Y, Matsuoka M, Huqun, Sutani A, Udagawa K, Zhang J, Hirama T, Murayama Y, Koyama N, Ikebuchi K, Nagata M, Kanazawa M, Nukiwa T, Takenoshita S, et al. Peptide nucleic acid-locked nucleic acid polymerase chain reaction clamp-based detection test for gefitinib-refractory T790M epidermal growth factor receptor mutation. Cancer Sci. 2008; 99: 595-600.

59. Whitcombe D, Theaker J, Guy SP, Brown T and Little S. Detection of PCR products using self-probing amplicons and fluorescence. Nat Biotechnol. 1999; 17: 804-807.

60. Guo K, Zhang Z, Han L, Han J, Wang J, Zhou Y, Liu H, Tong L, Li X and Yan X. Detection of epidermal growth factor receptor mutation in plasma as a biomarker in Chinese patients with early-stage non-small cell lung cancer. Onco Targets Ther. 2015; 8: 3289-3296.

61. Douillard JY, Ostoros G, Cobo M, Ciuleanu T, Cole R, McWalter G, Walker J, Dearden S, Webster A, Milenkova $\mathrm{T}$ and McCormack R. Gefitinib treatment in EGFR mutated caucasian NSCLC: circulating-free tumor DNA as a surrogate for determination of EGFR status. J Thorac Oncol. 2014; 9: 1345-1353.

62. Nielsen PE, Egholm M, Berg RH and Buchardt O. Sequence-selective recognition of DNA by strand displacement with a thymine-substituted polyamide. Science. 1991; 254: 1497-1500.

63. Miyazawa H, Tanaka T, Nagai Y, Matsuoka M, Huqun, Sutani A, Udagawa K, Zhang J, Hirama T, Murayama Y, Koyama N, Ikebuchi K, Nagata M, Kanazawa M, Nukiwa T, Takenoshita S, et al. Peptide nucleic acid-locked nucleic acid polymerase chain reaction clamp-based detection test for gefitinib-refractory T790M epidermal growth factor receptor mutation. Cancer Sci. 2008; 99: 595-600.

64. Anderson MW and Schrijver I. Next generation DNA sequencing and the future of genomic medicine. Genes (Basel). 2010; 1: 38-69.

65. Wang Q, Xia J, Jia P, Pao W and Zhao Z. Application of next generation sequencing to human gene fusion detection: computational tools, features and perspectives. Brief Bioinform. 2013; 14: 506-519.

66. Crowley E, Di Nicolantonio F, Loupakis F and Bardelli A. Liquid biopsy: monitoring cancer-genetics in the blood. Nat Rev Clin Oncol. 2013; 10: 472-484.

67. Guibert N, Pradines A, Farella M, Casanova A, Gouin S, Keller L, Favre G and Mazieres J. Monitoring KRAS mutations in circulating DNA and tumor cells using digital droplet PCR during treatment of KRAS-mutated lung adenocarcinoma. Lung Cancer. 2016; 100: 1-4.

68. Xu Q, Zhu Y, Bai Y, Wei X, Zheng X, Mao M and Zheng G. Detection of epidermal growth factor receptor mutation in lung cancer by droplet digital polymerase chain reaction. Onco Targets Ther. 2015; 8: 1533-1541.

69. Alegre E, Fusco JP, Restituto P, Salas-Benito D, RodriguezRuiz ME, Andueza MP, Pajares MJ, Patino-Garcia A, Pio R, Lozano MD, Gurpide A, Lopez-Picazo JM, Gil-Bazo I, Perez-Gracia JL and Gonzalez A. Total and mutated EGFR quantification in cell-free DNA from non-small cell lung cancer patients detects tumor heterogeneity and presents prognostic value. Tumour Biol. 2016; 37: 13687-13694. 
70. Tomasini P, Walia P, Labbe C, Jao K, Leighl NB. Targeting the KRAS Pathway in Non-Small Cell Lung Cancer. Oncologist. 2016; 21: 1450-1460.

71. Guibert N, Ilie M, Long E, Hofman V, Bouhlel L, Brest P, Mograbi B, Marquette CH, Didier A, Mazieres J and Hofman P. KRAS Mutations in Lung Adenocarcinoma: Molecular and Epidemiological Characteristics, Methods for Detection, and Therapeutic Strategy Perspectives. Curr Mol Med. 2015; 15: 418-432.

72. Spigal Dr SA, Fabrizio D, Frampton GM, Sun J, He J, Gowen K, Johsn LJ, Bauer TM, Kalemkerian GP, Raez LE, Ou SHI, Ross PJ, et al. . (2016). Total mutation burden (TMB) in lung cancer (LC) and relationship with response to PD-1/PD-L1 targeted therapies. ASCO; 9017.

73. Sozzi G, Roz L, Conte D, Mariani L, Andriani F, Lo Vullo $\mathrm{S}$, Verri $\mathrm{C}$ and Pastorino U. Plasma DNA quantification in lung cancer computed tomography screening: five-year results of a prospective study. Am J Respir Crit Care Med. 2009; 179: 69-74.

74. Nygaard AD, Holdgaard PC, Spindler KL, Pallisgaard N and Jakobsen A. The correlation between cell-free DNA and tumour burden was estimated by PET/CT in patients with advanced NSCLC. Br J Cancer. 2014; 110: 363-368.

75. Paez JG, Janne PA, Lee JC, Tracy S, Greulich H, Gabriel S, Herman P, Kaye FJ, Lindeman N, Boggon TJ, Naoki K, Sasaki H, Fujii Y, Eck MJ, Sellers WR, Johnson BE, et al. EGFR mutations in lung cancer: correlation with clinical response to gefitinib therapy. Science. 2004; 304: 1497 1500.

76. Marks JL, McLellan MD, Zakowski MF, Lash AE, Kasai Y, Broderick S, Sarkaria IS, Pham D, Singh B, Miner TL, Fewell GA, Fulton LL, Mardis ER, Wilson RK, Kris MG, Rusch VW, et al. Mutational analysis of EGFR and related signaling pathway genes in lung adenocarcinomas identifies a novel somatic kinase domain mutation in FGFR4. PLoS One. 2007; 2: e426.

77. Peifer M, Fernandez-Cuesta L, Sos ML, George J, Seidel D, Kasper LH, Plenker D, Leenders F, Sun R, Zander T, Menon R, Koker M, Dahmen I, Muller C, Di Cerbo V, Schildhaus HU, et al. Integrative genome analyses identify key somatic driver mutations of small-cell lung cancer. Nat Genet. 2012; 44: 1104-1110.

78. Sequist LV, Waltman BA, Dias-Santagata D, Digumarthy S, Turke AB, Fidias P, Bergethon K, Shaw AT, Gettinger S, Cosper AK, Akhavanfard S, Heist RS, Temel J, Christensen JG, Wain JC, Lynch TJ, et al. Genotypic and histological evolution of lung cancers acquiring resistance to EGFR inhibitors. Sci Transl Med. 2011; 3: 75ra26.

79. Sequist LV, Martins RG, Spigel D, Grunberg SM, Spira A, Janne PA, Joshi VA, McCollum D, Evans TL, Muzikansky A, Kuhlmann GL, Han M, Goldberg JS, Settleman J, Iafrate AJ, Engelman JA, et al. First-line gefitinib in patients with advanced non-small-cell lung cancer harboring somatic EGFR mutations. J Clin Oncol. 2008; 26: 2442-2449.

80. Kosaka T, Yatabe Y, Endoh H, Kuwano H, Takahashi T and Mitsudomi T. Mutations of the epidermal growth factor receptor gene in lung cancer: biological and clinical implications. Cancer Res. 2004; 64: 8919-8923.

81. Wang Z, Chen R, Wang S, Zhong J, Wu M, Zhao J, Duan J, Zhuo M, An T, Wang Y, Bai H and Wang J. Quantification and dynamic monitoring of EGFR T790M in plasma cell-free DNA by digital PCR for prognosis of EGFRTKI treatment in advanced NSCLC. PLoS One. 2014; 9: e110780.

82. Sorensen BS, Wu L, Wei W, Tsai J, Weber B, Nexo E and Meldgaard P. Monitoring of epidermal growth factor receptor tyrosine kinase inhibitor-sensitizing and resistance mutations in the plasma DNA of patients with advanced non-small cell lung cancer during treatment with erlotinib. Cancer. 2014; 120: 3896-3901.

83. Jänne PA, Yang JC, Kim DW, Planchard D, Ohe Y, Ramalingam SS, Ahn MJ, Kim SW, Su WC, Horn L, Haggstrom D, Felip E, Kim JH, et al. AZD9291 in EGFR inhibitor-resistant non-small-cell lung cancer. N Engl J Med. 2015; 372; 1689-1699.

84. Oxnard GR, Paweletz CP, Kuang Y, Mach SL, O'Connell A, Messineo MM, Luke JJ, Butaney M, Kirschmeier P, Jackman DM and Janne PA. Noninvasive detection of response and resistance in EGFR-mutant lung cancer using quantitative next-generation genotyping of cell-free plasma DNA. Clin Cancer Res. 2014; 20: 1698-1705.

85. Watanabe M, Kawaguchi T, Isa S, Ando M, Tamiya A, Kubo A, Saka H, Takeo S, Adachi H, Tagawa T, Kakegawa S, Yamashita M, Kataoka K, et al. Ultra-Sensitive Detection of the Pretreatment EGFR T790M Mutation in Non-Small Cell Lung Cancer Patients with an EGFR-Activating Mutation Using Droplet Digital PCR. Clin Cancer Res. 2015; 21: 3552-3560.

86. TR A. A case of cancer in which cells similar to those in the tumours were seen in the blood after death. Aust Med J. $1869 ; 14: 146-149$.

87. Aguirre-Ghiso JA. Models, mechanisms and clinical evidence for cancer dormancy. Nat Rev Cancer. 2007; 7: 834-846.

88. Aguirre-Ghiso JA. On the theory of tumor self-seeding: implications for metastasis progression in humans. Breast Cancer Res. 2010; 12: 304.

89. Pantel K, Alix-Panabières $\mathrm{C}$ and Riethdorf S. Cancer micrometastases. Nat Rev Clin Oncol. 2009; 6(6):339-351.

90. Kim MY, Oskarsson T, Acharyya S, Nguyen DX, Zhang $\mathrm{XH}$, Norton L and Massagué J. Tumor self-seeding by circulating cancer cells. Cell. 2009; 139: 1315-1326.

91. Hou JM, Krebs M, Ward T, Sloane R, Priest L, Hughes A, Clack G, Ranson M, Blackhall F and Dive C. Circulating tumor cells as a window on metastasis biology in lung cancer. Am J Pathol. 2011; 178: 989-996.

92. Hou JM, Krebs MG, Lancashire L, Sloane R, Backen A, Swain RK, Priest LJ, Greystoke A, Zhou C, Morris K, Ward T, Blackhall FH and Dive C. Clinical significance 
and molecular characteristics of circulating tumor cells and circulating tumor microemboli in patients with small-cell lung cancer. J Clin Oncol. 2012; 30: 525-532.

93. Hiltermann TJ, Pore MM, van den Berg A, Timens W, Boezen HM, Liesker JJ, Schouwink JH, Wijnands WJ, Kerner GS, Kruyt FA, Tissing H, Tibbe AG, Terstappen LW and Groen HJ. Circulating tumor cells in small-cell lung cancer: a predictive and prognostic factor. Ann Oncol. 2012; 23: 2937-2942.

94. Krebs MG, Hou JM, Sloane R, Lancashire L, Priest L, Nonaka D, Ward TH, Backen A, Clack G, Hughes A, Ranson M, Blackhall FH and Dive C. Analysis of circulating tumor cells in patients with non-small cell lung cancer using epithelial marker-dependent and -independent approaches. J Thorac Oncol. 2012; 7: 306-315.

95. Tanaka F, Yoneda K, Kondo N, Hashimoto M, Takuwa T, Matsumoto S, Okumura Y, Rahman S, Tsubota N, Tsujimura T, Kuribayashi K, Fukuoka K, Nakano T and Hasegawa S. Circulating tumor cell as a diagnostic marker in primary lung cancer. Clin Cancer Res. 2009; 15: 6980-6986.

96. Chang YS, di Tomaso E, McDonald DM, Jones R, Jain RK and Munn LL. Mosaic blood vessels in tumors: frequency of cancer cells in contact with flowing blood. Proc Natl Acad Sci U S A. 2000; 97: 14608-14613.

97. Calabuig-Farinas S, Jantus-Lewintre E, Herreros-Pomares A and Camps C. Circulating tumor cells versus circulating tumor DNA in lung cancer-which one will win? Transl Lung Cancer Res. 2016; 5: 466-482.

98. Farace F, Massard C, Vimond N, Drusch F, Jacques N, Billiot F, Laplanche A, Chauchereau A, Lacroix L, Planchard D, Le Moulec S, Andre F, Fizazi K, Soria JC and Vielh P. A direct comparison of CellSearch and ISET for circulating tumour-cell detection in patients with metastatic carcinomas. Br J Cancer. 2011; 105: 847-853.

99. Tao D, Han X, Zhang N, Lin D, Wu D, Zhu X, Song W and Shi Y. Genetic alteration profiling of patients with resected squamous cell lung carcinomas. Oncotarget. 2016; 7: 36590-36601.

100. George J, Lim JS, Jang SJ, Cun Y, Ozretic L, Kong G, Leenders F, Lu X, Fernandez-Cuesta L, Bosco G, Muller C, Dahmen I, Jahchan NS, Park KS, Yang D, Karnezis AN, et al. Comprehensive genomic profiles of small cell lung cancer. Nature. 2015; 524: 47-53.

101. Farace F, Massard C, Vimond N, Drusch F, Jacques N, Billiot F, Laplanche A, Chauchereau A, Lacroix L, Planchard D, Le Moulec S, Andre F, Fizazi K, Soria JC and Vielh P. A direct comparison of CellSearch and ISET for circulating tumour-cell detection in patients with metastatic carcinomas. Br J Cancer. 2011; 105: 847-853.

102. Lecharpentier A, Vielh P, Perez-Moreno P, Planchard D, Soria JC and Farace F. Detection of circulating tumour cells with a hybrid (epithelial/mesenchymal) phenotype in patients with metastatic non-small cell lung cancer. Br J Cancer. 2011; 105: 1338-1341.

103. Pailler E, Adam J, Barthelemy A, Oulhen M, Auger N,
Valent A, Borget I, Planchard D, Taylor M, Andre F, Soria JC, Vielh P, Besse B and Farace F. Detection of circulating tumor cells harboring a unique ALK rearrangement in ALKpositive non-small-cell lung cancer. J Clin Oncol. 2013; 31 : 2273-2281.

104. Pailler E, Auger N, Lindsay CR, Vielh P, Islas-MorrisHernandez A, Borget I, Ngo-Camus M, Planchard D, Soria JC, Besse B and Farace F. High level of chromosomal instability in circulating tumor cells of ROS1-rearranged non-small-cell lung cancer. Ann Oncol. 2015; 26: 14081415.

105. Sarioglu AF, Aceto N, Kojic N, Donaldson MC, Zeinali M, Hamza B, Engstrom A, Zhu H, Sundaresan TK, Miyamoto DT, Luo X, Bardia A, Wittner BS, Ramaswamy S, Shioda T, Ting DT, et al. A microfluidic device for label-free, physical capture of circulating tumor cell clusters. Nat Methods. 2015; 12: 685-691.

106. Ntouroupi TG, Ashraf SQ, McGregor SB, Turney BW, Seppo A, Kim Y, Wang X, Kilpatrick MW, Tsipouras P, Tafas T and Bodmer WF. Detection of circulating tumour cells in peripheral blood with an automated scanning fluorescence microscope. Br J Cancer. 2008; 99: 789-795.

107. Ross JS and Slodkowska EA. Circulating and disseminated tumor cells in the management of breast cancer. Am J Clin Pathol. 2009; 132: 237-245.

108. Sergeant G, Penninckx F and Topal B. Quantitative RT-PCR detection of colorectal tumor cells in peripheral blood-a systematic review. J Surg Res. 2008; 150: 144-152.

109. Yoon HJ, Kim TH, Zhang Z, Azizi E, Pham TM, Paoletti C, Lin J, Ramnath N, Wicha MS, Hayes DF, Simeone DM and Nagrath S. Sensitive capture of circulating tumour cells by functionalized graphene oxide nanosheets. Nat Nanotechnol. 2013; 8: 735-741.

110. Hodgkinson CL, Morrow CJ, Li Y, Metcalf RL, Rothwell DG, Trapani F, Polanski R, Burt DJ, Simpson KL, Morris K, Pepper SD, Nonaka D, Greystoke A, Kelly P, Bola B, Krebs MG, et al. Tumorigenicity and genetic profiling of circulating tumor cells in small-cell lung cancer. Nat Med. 2014; 20: 897-903.

111. Kolostova K, Zhang Y, Hoffman RM and Bobek V. In vitro culture and characterization of human lung cancer circulating tumor cells isolated by size exclusion from an orthotopic nude-mouse model expressing fluorescent protein. J Fluoresc. 2014; 24: 1531-1536.

112. Maheswaran S, Sequist LV, Nagrath S, Ulkus L, Brannigan B, Collura CV, Inserra E, Diederichs S, Iafrate AJ, Bell DW, Digumarthy S, Muzikansky A, Irimia D, Settleman J, Tompkins RG, Lynch TJ, et al. Detection of mutations in EGFR in circulating lung-cancer cells. N Engl J Med. 2008; 359: 366-377.

113. Aieta M, Facchinetti A, De Faveri S, Manicone M, Tartarone A, Possidente L, Lerose R, Mambella G, Calderone G, Zamarchi R and Rossi E. Monitoring and Characterization of Circulating Tumor Cells (CTCs) in a Patient With EML4-ALK-Positive Non-Small Cell Lung 
Cancer (NSCLC). Clin Lung Cancer. 2016; 17: e173-e177.

114. Ilie M, Long E, Butori C, Hofman V, Coelle C, Mauro V, Zahaf K, Marquette CH, Mouroux J, Paterlini-Brechot P and Hofman P. ALK-gene rearrangement: a comparative analysis on circulating tumour cells and tumour tissue from patients with lung adenocarcinoma. Ann Oncol. 2012; 23: 2907-2913.

115. Guibert N, Pradines A, Farella M, Casanova A, Gouin S, Keller L, Favre G and Mazieres J. Monitoring KRAS mutations in circulating DNA and tumor cells using digital droplet PCR during treatment of KRAS-mutated lung adenocarcinoma. Lung Cancer. 2016; 100: 1-4.

116. Daly ME. Haematologica January 2011 96: 10-13.

117. Best MG, Sol N, Kooi I, Tannous J, Westerman BA, Rustenburg F, Schellen P, Verschueren H, Post E, Koster J, Ylstra B, Ameziane N, Dorsman J, Smit EF, Verheul HM, Noske DP, et al. RNA-Seq of Tumor-Educated Platelets Enables Blood-Based Pan-Cancer, Multiclass, and Molecular Pathway Cancer Diagnostics. Cancer Cell. 2015; 28: 666-676.

118. Nilsson RJ, Balaj L, Hulleman E, van Rijn S, Pegtel DM, Walraven M, Widmark A, Gerritsen WR, Verheul HM, Vandertop WP, Noske DP, Skog J and Würdinger T. Blood platelets contain tumor-derived RNA biomarkers. Blood. 2011; 118: 3680-3683.

119. Power KA, McRedmond JP, de Stefani A, Gallagher WM, Gaora PO. High-throughput proteomics detection of novel splice isoforms in human platelets. PLoS One. 2009; 4: e5001.

120. Konerding MA, Malkusch W, Klapthor B, van Ackern C, Fait E, Hill SA, Parkins C, Chaplin DJ, Presta M and Denekamp J. Evidence for characteristic vascular patterns in solid tumours: quantitative studies using corrosion casts. Br J Cancer. 1999; 80: 724-732.

121. Dudley AC. Tumor endothelial cells. Cold Spring Harb Perspect Med. 2012; 2: a006536.

122. Mrvar-Brecko A, Sustar V, Jansa V, Stukelj R, Jansa R, Mujagic E, Kruljc P, Iglic A, Hagerstrand $\mathrm{H}$ and Kralj-Iglic $\mathrm{V}$. Isolated microvesicles from peripheral blood and body fluids as observed by scanning electron microscope. Blood Cells Mol Dis. 2010; 44: 307-312.

123. Pisitkun T, Shen RF and Knepper MA. Identification and proteomic profiling of exosomes in human urine. Proc Natl Acad Sci U S A. 2004; 101: 13368-13373.

124. Andre F, Schartz NE, Movassagh M, Flament C, Pautier P, Morice P, Pomel C, Lhomme C, Escudier B, Le Chevalier T,
Tursz T, Amigorena S, Raposo G, Angevin E and Zitvogel L. Malignant effusions and immunogenic tumour-derived exosomes. Lancet. 2002; 360: 295-305.

125. Raposo G and Stoorvogel W. Extracellular vesicles: exosomes, microvesicles, and friends. J Cell Biol. 2013; 200: 373-383.

126. Thakur BK, Zhang H, Becker A, Matei I, Huang Y, CostaSilva B, Zheng Y, Hoshino A, Brazier H, Xiang J, Williams C, Rodriguez-Barrueco R, Silva JM, Zhang W, Hearn S, Elemento O, et al. Double-stranded DNA in exosomes: a novel biomarker in cancer detection. Cell Res. 2014; 24 : 766-769.

127. Roma-Rodrigues C, Fernandes AR and Baptista PV. Exosome in tumour microenvironment: overview of the crosstalk between normal and cancer cells. Biomed Res Int. 2014; 2014:179486.

128. Lin J, Wang Y, Zou YQ, Chen X, Huang B, Liu J, Xu YM, Li J, Zhang J, Yang WM, Min QH, Sun F, Li SQ, Gao QF and Wang XZ. Differential miRNA expression in pleural effusions derived from extracellular vesicles of patients with lung cancer, pulmonary tuberculosis, or pneumonia. Tumour Biol. 2016, in press.

129. Rabinowits G, Gercel-Taylor C, Day JM, Taylor DD and Kloecker GH. Exosomal microRNA: a diagnostic marker for lung cancer. Clin Lung Cancer. 2009; 10: 42-46.

130. Sandfeld-Paulsen B, Aggerholm-Pedersen N, Baek R, Jakobsen KR, Meldgaard P, Folkersen BH, Rasmussen TR, Varming K, Jorgensen MM and Sorensen BS. Exosomal proteins as prognostic biomarkers in non-small cell lung cancer. Mol Oncol. 2016; 10(10):1595-1602.

131. Brinkmann K ED, Koestler T, Bentink S, Emenegger J, Spiel A, Mueller R, O’Neill V, Skog J, Noerholm M. (2015). Plasma-based diagnostics for detection of EML4ALK fusion transcripts in NSCLC patients. AACR: Cancer Research), pp. 545.

132. Krug AK KC, Koestler T, Brinkmann K, Spile A, Emenenegger J, Noerholm M, O’Neill V, Sequist LV, Soria JC, Goldman JW, Camidge DR, Wakelee HA, et al. (2016). Plasma EGFR mutation detection using a combined exosomal RNA and circulating tumor DNA approach in patients with acquired resistance to first-generation EGFRTKIs. AACR: Cancer Research).

133. Ralla B, Stephan C, Meller S, Dietrich D, Kristiansen G, Jung K. Nucleic acid-based biomarkers in body fluids of patients with urologic malignancies. Crit Rev Clin Lab Sci. 2014; 51: 200-231. 